\title{
Effectiveness of acupuncture, ozonio therapy and low-intensity laser in the treatment of temporomandibular dysfunction of muscle origin: a randomized controlled trial
}

Efetividade da acupuntura, ozonioterapia e do laser de baixa intensidade no tratamento da disfunção temporomandibular de origem muscular: um ensaio clínico randomizado

\author{
Síglia Adriana Campos TORTELLI ${ }^{\mathrm{a}}$ (1) , Leonardo SARAIVA $^{\mathrm{a}^{*}}$ (D), Daniela Cristina MIYAGAKI ${ }^{\mathrm{a}}$ (1) \\ aUPF - Universidade de Passo Fundo, Passo Fundo, RS, Brasil
}

\begin{abstract}
How to cite: Tortelli SAC, Saraiva L, Miyagaki DC. Effectiveness of acupuncture, ozonio therapy and low-intensity laser in the treatment of temporomandibular dysfunction of muscle origin: a randomized controlled trial. Rev Odontol UNESP. 2019;48:e20190107. https://doi.org/10.1590/1807-2577.10719
\end{abstract}

\begin{abstract}
Resumo
Introdução: Uma das causas mais comuns de dores orofaciais é a disfunção temporomandibular (DTM). Objetivo: 0 objetivo deste estudo foi comparar a efetividade da acupuntura, ozonioterapia e laserterapia no tratamento de pacientes com DTM muscular, através de um ensaio clínico randomizado. Material e método: Foram avaliados 12 professores e estudantes de pós-graduação da Universidade de Passo Fundo, diagnosticados com DTM, com faixa etária entre 23 e 50 anos, de ambos os sexos. Os indivíduos foram divididos aleatoriamente em 3 grupos: G1: laserterapia, G2: acupuntura, e G3: ozonioterapia. Foram aplicados questionários de diagnóstico de DTM (RDC/TMD), questionário de Qualidade de Vida (OHIP-14), Escala de dor (EVA) e mensuração de abertura bucal máxima. Para caracterização da amostra, utilizaram-se estatísticas descritivas e percentagem, que foram apresentadas empregando-se distribuições de frequências absolutas e relativas. As variáveis qualitativas foram analisadas com os testes de Wilcoxon $p \leq 0,05$. Resultado: Não houve diferença estatisticamente significativa entre os tratamentos. Em relação a dor e a abertura bucal máxima, os grupos não apresentaram diferença estatística quando analisados individualmente, mas quando comparados de maneira geral, apresentaram diferenças estatísticas ( $p=0,002$ e $p=0,003$ ). Conclusão: Pode-se considerar que todos os tratamentos foram capazes de diminuir a dor e melhorar a capacidade de abertura bucal máxima relacionadas à DTM muscular. Pode-se concluir ainda que a qualidade de vida relacionada à DTM, em relação a variável dor, de uma maneira geral mostrou-se efetiva quando comparada antes e após as intervenções.
\end{abstract}

Descritores: Transtornos da articulação temporomandibular; terapia a laser; terapia por acupuntura; ozonioterapia.

\begin{abstract}
Introduction: One of the most common causes of orofacial pain is temporomandibular disorder (TMD). Objective: The aim of this study was to compare the effectiveness of acupuncture, ozone therapy and laser therapy in the treatment of muscle TMD patients through a randomized controlled trial. Material and method: Twelve professors and postgraduate students from the University of Passo Fundo, diagnosed with TMD, aged between 23 and 50 years old, of both sexes, were evaluated. Individuals were randomly divided into 3 groups: G1: laser therapy, G2: acupuncture, and G3: ozone therapy. TMD diagnostic questionnaires (RDC / TMD), Quality of Life Questionnaire (OHIP-14), Pain Scale (VAS) and maximum mouth opening were applied. Descriptive statistics and percentage were used for sample characterization, which were presented using absolute and relative frequency distributions. Qualitative variables were analyzed with Wilcoxon tests $\mathrm{p} \leq 0.05$. Result: There was no statistically significant difference between treatments. Regarding pain
\end{abstract}


and maximum mouth opening, the groups showed no statistical difference when individually analyzed, but when compared in general, they did $(\mathrm{p}=0.002$ and $\mathrm{p}=0.003)$. Conclusion: It can be considered that all treatments were able to decrease pain and improve maximal opening capacity related to muscle TMD. It can also be concluded that the TMD-related quality of life, in relation to the pain variable, was generally effective when compared before and after the interventions.

Descriptors: Temporomandibular joint; temporomandibular joint disorders; laser therapy; acupuncture therapy; ozone.

\section{INTRODUCTION}

For the American Academy of Orofacial Pain (AAOP) TMD is defined as a set of pain and/or dysfunctional conditions related to masticatory muscles, temporomandibular joints (TMJs) and nearby structures ${ }^{1}$.

Because it is a multifactorial disorder, TMD may be related to several factors, including psychological, structural, parafunctional, occlusal or degenerative factors 2 .

TMD is a disorder that increases over the years and consequently increases its prevalence in the population. At least $40 \%$ have already presented some sign of this dysfunction, such as noise and more than $30 \%$ have at least one symptom, such as pain in the $\mathrm{ATM}^{3}$; considering that young adults aged 13 to 35 years are the most affected population due to greater exposure to stressors, and the correlation between physical pain and emotional stress has been proven 4

There are several treatments indicated for TMD, and most of them have an effect on pain minimization, muscle relaxation and increased mouth opening 5 . Several types of treatment are studied and used, including botulinum toxin, myorelaxant plaque, physiotherapy, electrotherapy, low-intensity laser, acupuncture and surgical treatments in some cases. However, the literature with controlled clinical studies is still controversial regarding the treatment of TMD with these types of methods 5 .

One of the recommended treatments is acupuncture, which consists of stimulating specific points along the body skin, involving various methods, such as penetrating thin needles or applying heat, pressure or laser light ${ }^{6}$. Acupuncture can help relieve the discomfort and pain associated with these conditions as it may rebalance circulating energy (Qi) in the meridians and studies have shown its effectiveness in pain control ${ }^{6}$.

Low-intensity laser is one of the treatment modalities in dentistry and has been widely used in the health field for therapeutic and bio stimulation purposes ${ }^{7}$. It is a highly concentrated electromagnetic light that in contact with the tissue can result in several effects, influencing the synthesis, release and metabolism of numerous signaling substances involved in analgesia, through direct irradiation without causing thermal response ${ }^{7}$.

Another treatment that has been extensively studied for TMD is ozone ${ }^{8,9}$, allowing promising results to be obtained. Ozone is used worldwide for many diseases as it is highly effective against viruses, bacteria and fungi, and has anti-inflammatory action. It acts to increase local oxygen supply, promoting local homeostasis and inhibiting bacterial proliferation in many diseases, including cancer and rheumatoid arthritis ${ }^{10,11}$.

Therefore, the aim of this study was to evaluate the effectiveness of acupuncture, ozone therapy, and low-level laser in pain perception and in improving the quality of life of TMD students and postgraduate teachers. The hypothesis of the study is that acupuncture, ozone therapy and low-intensity laser will be effective in pain perception and in improving the quality of life of patients suffering from temporomandibular dysfunction. 


\section{MATERIAL AND METHOD}

The study is characterized as a randomized controlled trial. Twelve stricto sensu postgraduate professors and students from the University of Passo Fundo, proven to have muscular TMD, divided into 3 groups ( $n=4)$, aged between 23 and 50 years, of both sexes, were evaluated.

This study was submitted to the Research Ethics Committee of the University of Passo Fundo, approved with the opinion number: 3.006.284. The research complies with Resolution 466/2012 of the National Health Council, which deals with regulatory standards and ethical aspects of research involving human beings.

Individuals with unilateral or bilateral myofascial pain, mutually protected occlusion, reports of clenching or signs of tooth attrition were included. Exclusion criteria were: pregnancy or lactation during the study, use of systemic drugs that interfere with the musculoskeletal system or stress level, current use of myorelaxant plaques; use of full dentures, Bränemark protocols and removable partial dentures; reports of psychiatric problems or depression, cancer patients and needle phobia patients.

All participants answered the RDC/TMD (Research Diagnostic Criteria for Temporomandibular Disorders) questionnaires for TMD diagnosis ${ }^{12}$; Quality of Life Questionnaire (OHIP-14) ${ }^{13}$, VAS (Visual Analogue Scale) pain scale and maximum mouth opening measurement.

After selecting the 12 patients, 3 groups were created with 04 patients each $(n=4)$. For this, the patients were numbered from 1 to 12 and after that, the site Research Randomizer ${ }^{14}$ was used to randomize the samples, and the first group received low-intensity laser treatment, the second group received acupuncture treatment, and the third group received treatment with ozone therapy. Pain perception was measured using the Visual Analogue Scale (VAS) before the first application of each therapy, immediately and after the last session and 30 days after treatment. Maximum mouth opening was measured using a specific, flexible, standardized millimeter-sized ruler for individual use (JON, Trade-in Dental Products, São Paulo, Brazil). Individuals were instructed to perform the maximum mouth opening and hold until the examiner completed the procedure.

According to the manufacturer of the Therapy EC device (DMC Equipment ${ }^{\circledR}$, São Carlos, SP, Brazil), individuals from the laser therapy group received the application of low-intensity laser, infrared light, wavelength: $808 \mathrm{~nm} \pm 10 \mathrm{~nm}$. Useful intensity Infrared laser emitter: $100 \mathrm{~mW} \pm 20 \%$, being applied at target points (over bilateral anterior temporal and masseter muscles $)^{15} 2 \mathrm{~J}$, with $72 \mathrm{~h}$ intervals, for a total of six sessions.

In the group that received acupuncture a protocol of local and distal points proposed by Rosted ${ }^{6}$ was used, where local points on the face and neck are recommended: ST-6, ST-7, SI-18, GV-20, GB-20, BL-10. As a distant point, the LI-4 is recommended. They were performed by a qualified professional, totaling six sessions, lasting 30 minutes each, once a week. Acupuncture needles (Dongbang ${ }^{\circledR}$, Dongbang FTL Co, Seoul, South Korea) were used in the $0.25 \mathrm{~mm}$ x $30 \mathrm{~mm}$ measurements.

In the patients of the Ozone Therapy group, the Philozon Medplus ${ }^{\circledR}$ ozone generator (Philozon, Balneário Camboriú, Santa Catarina, Brazil) was used, with ozone - oxygen concentration of $10-20 \mu \mathrm{g} / \mathrm{mL}$, placed in a $5 \mathrm{~mL}$ syringe ${ }^{16}$. A $0.8 \times 40 \mathrm{~mm}$ needle was used and inserted intramuscularly into the trigger points of the masseter and temporal muscles bilaterally. Injecting 0.1 to $0.3 \mathrm{~mL}$ to $1 \mathrm{~mL}$ (maximum product on each side) twice a week for a total of six sessions.

For sample characterization, descriptive statistics and percentage were used, which were presented using univariate (absolute and relative) frequency distributions, as well as bi and multivariate contingency tables. Quantitative variables were described by measures of central 
tendency or position (mean, median, average rank) and variability (standard deviation, 25 th and 75th percentiles, minimum and maximum).

Data with non-normal distribution (pain) were analyzed using the Wilcoxon test for comparison between groups and for analysis in each group over time. All analyses were performed using the Statistical Package for Social Sciences (SPSS) software, version 22.0, considering $p \leq 0.05$.

\section{RESULT}

Table 1 shows the sample characterization according to the RDC questionnaire. The sample consisted of 12 individuals, with a mean age of 32.83 years, most of them female $(83.3 \%)$, leucoderms (75\%), single (58.3\%) and income of two times the minimum wage. $(41.7 \%)$. Regarding facial pain, 12 participants $(100 \%)$ reported having facial pain in the last month, $10(83.3 \%)$ reported that facial pain is recurrent and $11(91.7 \%)$ reported feeling pain or stiffness. TMJ in the morning. Individuals reported TMJ symptoms, crackling (100\%), and headache $(91.7 \%)$. In addition, many were prevented from performing basic activities such as yawning (75\%) and eating hard foods (66.7\%).

Table 1. Characterization of the sample according to the RDC / TMD questionnaire

\begin{tabular}{|c|c|c|}
\hline Variables & $\mathbf{N}$ & $\%$ \\
\hline Age (mean and standard deviation) & \multicolumn{2}{|c|}{$32.83 \pm 8.60$} \\
\hline \multicolumn{3}{|l|}{ Sex } \\
\hline Male & 2 & 16.7 \\
\hline Female & 10 & 83.3 \\
\hline \multicolumn{3}{|l|}{ Source } \\
\hline European (leucoderms) & 7 & 58.3 \\
\hline South-American (meloderm) & 3 & 25.0 \\
\hline Other & 2 & 16.7 \\
\hline \multicolumn{3}{|l|}{ Origin ancestors } \\
\hline African & 2 & 16.7 \\
\hline European & 9 & 75.0 \\
\hline Others & 1 & 8.3 \\
\hline \multicolumn{3}{|l|}{ School grade } \\
\hline Higher Education & 5 & 41.7 \\
\hline Masters / Doctorate & 7 & 58.3 \\
\hline \multicolumn{3}{|l|}{ Marital status } \\
\hline Married in the same room & 4 & 33.3 \\
\hline Divorced & 1 & 8.3 \\
\hline Never married & 7 & 58.3 \\
\hline \multicolumn{3}{|l|}{ Income } \\
\hline 0 to minimum wage & 1 & 8.3 \\
\hline Twice the minimum wage & 5 & 41.7 \\
\hline Three times the minimum wage & 1 & 8.3 \\
\hline Four times the minimum wage & 1 & 8.3 \\
\hline Eight times the minimum wage & 2 & 16.7 \\
\hline \multirow[t]{2}{*}{ Nine times the minimum wage } & 2 & 16.7 \\
\hline & $\mathrm{N}$ & $\%$ \\
\hline Facial pain in the last month & 12 & $100 \%$ \\
\hline Onset of facial pain (years) & \multicolumn{2}{|c|}{$6.25 \pm 3.27$} \\
\hline
\end{tabular}


Table 1. Continued...

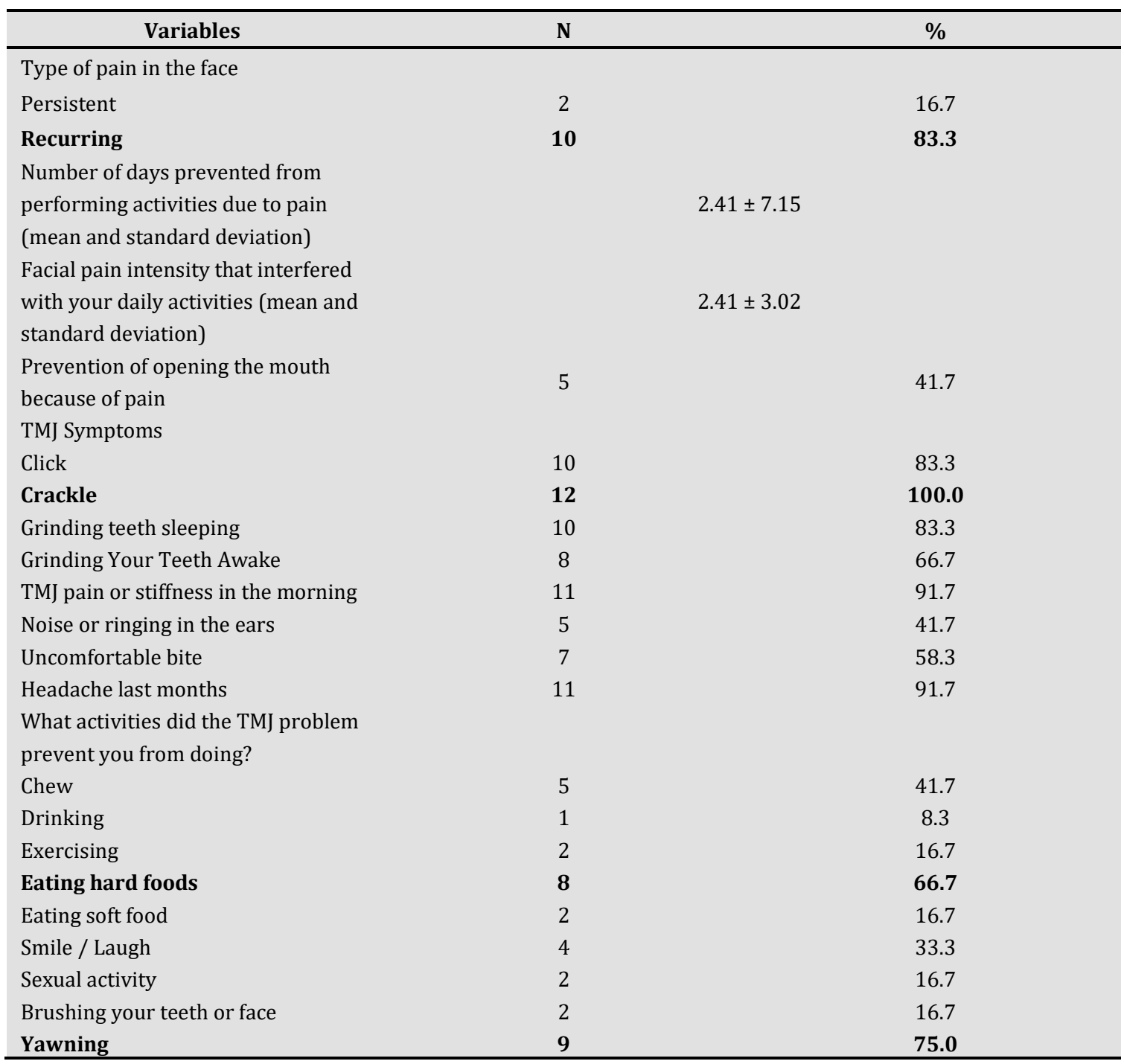

Subtitle: $\mathrm{n}$ (absolute value); \% (relative value).

Regarding the Quality of Life questionnaire (OHIP-14) (Table 2), all questions sought to relate the oral condition to their themes. It can be observed that there was no statistically significant difference in the comparison within each isolated group, either pre-intervention or post-intervention. However, when all groups were analyzed together, there was a significant difference in pain-related QoL ( $p=0.012)$ and physical inactivity $(p=0.028)$.

Table 2. Comparison of dependent variables before and after intervention

\begin{tabular}{|c|c|c|c|c|c|c|c|c|}
\hline \multirow{2}{*}{$\begin{array}{c}\text { Group } \\
\text { Acupuncture }\end{array}$} & \multirow[t]{2}{*}{ Variable } & \multicolumn{3}{|c|}{ Pre-intervention } & \multicolumn{3}{|c|}{ Post-intervention } & \multirow[t]{2}{*}{$\begin{array}{c}\text { Value } \\
p^{*} \\
\end{array}$} \\
\hline & & Q1 & Median & Q3 & Q1 & Median & Q3 & \\
\hline & QOL Functional Limitation & 0.00 & 0.00 & 0.00 & 0.00 & 0.50 & 1.75 & 0.180 \\
\hline & QOL Pain & 4.00 & 4.50 & 6.50 & 1.50 & 4.00 & 5.75 & 0.102 \\
\hline & QOL Psychological Discomfort & 2.50 & 5.00 & 7.50 & 2.00 & 3.00 & 6.25 & 0.655 \\
\hline & QL Physical Disability & 0.00 & 2.00 & 4.75 & 0.00 & 0.00 & .75 & 0.157 \\
\hline & QOL Psychological Disability & 1.25 & 2.50 & 4.50 & 2.00 & 3.00 & 5.50 & 0.593 \\
\hline & QV Social Disability & 1.25 & 2.00 & 2.75 & 1.00 & 2.50 & 4.00 & 0.564 \\
\hline & QL Disability & 0.25 & 1.00 & 1.00 & 0.00 & 0.50 & 3.25 & 0.655 \\
\hline \multicolumn{9}{|l|}{ Laser Therapy } \\
\hline & QL Functional Limitation & .00 & .50 & 2.50 & .00 & .00 & .00 & 0.180 \\
\hline
\end{tabular}


Table 2. Continued...

\begin{tabular}{|c|c|c|c|c|c|c|c|c|}
\hline \multirow[t]{2}{*}{ Group } & \multirow{2}{*}{$\begin{array}{l}\text { Variable } \\
\text { QOL Pain }\end{array}$} & \multicolumn{3}{|c|}{ Pre-intervention } & \multicolumn{3}{|c|}{ Post-intervention } & \multirow{2}{*}{$\begin{array}{c}\begin{array}{c}\text { Value } \\
\boldsymbol{p}^{*}\end{array} \\
0.257\end{array}$} \\
\hline & & 1.25 & 2.50 & 4.50 & .25 & 1.50 & 2.00 & \\
\hline & QOL Psychological Discomfort & .75 & 3.50 & 5.50 & 1.00 & 4.00 & 5.50 & 0.785 \\
\hline & QL Physical Disability & .00 & 1.00 & 5.00 & .00 & .00 & 1.50 & 0.414 \\
\hline & QOL Psychological Disability & 1.25 & 2.50 & 3.00 & 2.00 & 2.50 & 3.00 & 0.564 \\
\hline & QV Social Inability & .00 & 2.00 & 4.0 & .25 & 1.50 & 2.00 & 0.581 \\
\hline & QL Disability & .00 & .50 & 2.50 & .00 & .00 & 2.25 & 0.785 \\
\hline \multicolumn{9}{|c|}{ Ozone Therapy } \\
\hline & QOL Functional Limitation & 0.50 & 2.00 & 2.75 & 0.00 & 0.00 & 3.00 & 0.276 \\
\hline & QOL Pain & 4.00 & 4.00 & 5.50 & 1.25 & 2.50 & 5.25 & 0.109 \\
\hline & QOL Psychological Discomfort & 4.25 & 5.50 & 6.75 & 1.25 & 4.50 & 7.75 & 0.705 \\
\hline & QL Physical Disability & 2.25 & 3.00 & 6.75 & 0.00 & 0.50 & 2.50 & 0.144 \\
\hline & QOL Psychological Disability & 3.00 & 3.50 & 5.50 & 1.00 & 2.50 & 4.00 & 0.083 \\
\hline & QL Social Inability & 2.50 & 4.00 & 6.25 & 0.50 & 3.00 & 4.75 & 0.083 \\
\hline & QL Disability & 1.00 & 1.50 & 4.25 & 0.00 & 1.00 & 2.75 & 0.593 \\
\hline \multicolumn{9}{|l|}{ Total } \\
\hline & QOL Functional Limitation & .00 & .00 & 2.00 & .00 & .00 & .75 & 0.391 \\
\hline & QOL Pain & 3.25 & 4.00 & 5.00 & 1.00 & 2.00 & 4.50 & 0.012 \\
\hline & QOL Psychological Discomfort & 3.25 & 4.50 & 6.00 & 2.00 & 4.00 & 6.75 & 0.631 \\
\hline & QL Physical Disability & .00 & 2.50 & 4.75 & .00 & .00 & 1.00 & 0.028 \\
\hline & QOL Psychological Disability & 2.00 & 3.00 & 3.75 & 2.00 & 2.50 & 4.00 & 0.472 \\
\hline & QL Social Inability & 1.25 & 2.50 & 4.00 & 1.00 & 2.00 & 4.00 & 0.280 \\
\hline & QL Disability & .25 & 1.00 & 1.75 & .00 & .00 & 2.75 & 0.777 \\
\hline
\end{tabular}

Subtitle: Q1 (first quartile); Q3 (third quartile); ${ }^{*}$ Wilcoxon test). In bold $(\mathrm{p}<0.05)$.

Regarding pain (VAS scale) and maximum mouth opening, there were no statistical differences in the groups individually. However, when the groups were analyzed in general, the variable pain and maximum mouth opening showed statistical differences ( $p=0.002$ and $p=0.003$ ) respectively (Table 3).

Table 3. Comparison between the variables pain (VAS) and maximum mouth opening before and after intervention

\begin{tabular}{|c|c|c|c|c|c|c|c|c|}
\hline \multirow[t]{2}{*}{ Group } & \multirow[t]{2}{*}{ Variable } & \multicolumn{3}{|c|}{ Pre-intervention } & \multicolumn{3}{|c|}{ Post-intervention } & \multirow[t]{2}{*}{$\begin{array}{c}\text { Value } \\
p^{*}\end{array}$} \\
\hline & & Q1 & Median & Q3 & Q1 & Median & Q3 & \\
\hline \multirow[t]{2}{*}{ Acupuncture } & Pain (VAS) & 1.62 & 4.83 & 5.66 & 0.75 & 3.58 & 4.66 & 0.066 \\
\hline & Mouth Opening & 3.91 & 4.58 & 4.91 & 4.18 & 4.59 & 5.09 & 0.109 \\
\hline \multirow[t]{2}{*}{ Laser Therapy } & Pain (VAS) & 3.45 & 4.41 & 5.12 & 2.00 & 2.00 & 2.12 & 0.068 \\
\hline & Mouth Opening & 3.52 & 4.20 & 4.86 & 3.91 & 4.48 & 5.15 & 0.068 \\
\hline \multirow[t]{2}{*}{ Ozone Therapy } & Pain (VAS) & 2.75 & 3.75 & 5.62 & 0.50 & 1.16 & 1.33 & 0.068 \\
\hline & Mouth Opening & 3.69 & 3.91 & 4.50 & 4.25 & 4.43 & 4.82 & 0.068 \\
\hline \multirow[t]{2}{*}{ Total } & Pain (VAS) & 3.37 & 4.00 & 5.54 & 1.08 & 2.00 & 2.41 & 0.002 \\
\hline & Mouth Opening & 3.72 & 4.23 & 4.77 & 4.16 & 4.46 & 4.88 & 0.003 \\
\hline
\end{tabular}

Subtitle: Q1 (first quartile); Q3 (third quartile); * Wilcoxon test). In bold $(p<0.05)$.

There was no statistical difference in the comparison of pain and mouth opening between pre-intervention and 30 days after treatment and between immediate post-intervention and 30 days after treatment, isolated by group. However, there was a statistical difference in the overall groups in the immediate pre-intervention and 30 days after treatment $(p=0.010)$ (Table 4). 
Table 4. Comparison of pain and mouth opening between pre-intervention and 30 days after treatment and between immediate post-intervention and 30 days after treatment

\begin{tabular}{|c|c|c|c|c|c|c|c|c|}
\hline Group & Variable & \multicolumn{3}{|c|}{ Pre-intervention } & \multicolumn{3}{|c|}{$\begin{array}{c}30 \text { days after the } \\
\text { intervention }\end{array}$} & \\
\hline \multirow{7}{*}{ Acupuncture } & & Q1 & Median & Q3 & Q1 & Median & Q3 & Value $p$ \\
\hline & Pain (VAS) & 1.62 & 4.83 & 5.66 & 0.50 & 3.50 & 7.25 & 1.00 \\
\hline & Mouth Opening & 3.91 & 4.58 & 4.91 & 4.05 & 4.60 & 5.07 & 0.715 \\
\hline & & \multicolumn{3}{|c|}{ Immediate post-intervention } & \multicolumn{3}{|c|}{$\begin{array}{c}30 \text { days after the } \\
\text { intervention }\end{array}$} & \\
\hline & & Q1 & Median & Q3 & Q1 & Median & Q3 & Value $p$ \\
\hline & Pain (VAS) & 0.75 & 3.58 & 4.66 & 0.50 & 3.50 & 7.25 & 0.465 \\
\hline & Mouth Opening & 4.18 & 4.59 & 5.09 & 4.05 & 4.60 & 5.07 & 0.715 \\
\hline \multirow{8}{*}{ Laser Therapy } & & \multicolumn{3}{|c|}{ Pre-intervention } & \multicolumn{3}{|c|}{$\begin{array}{c}30 \text { days after the } \\
\text { intervention }\end{array}$} & \\
\hline & & Q1 & Median & Q3 & Q1 & Median & Q3 & Value $p$ \\
\hline & Pain (VAS) & 3.45 & 4.41 & 5.12 & 0.00 & 1.50 & 4.50 & 0.109 \\
\hline & Mouth Opening & 3.52 & 4.20 & 4.86 & 4.05 & 4.60 & 5.37 & 1.000 \\
\hline & & \multicolumn{3}{|c|}{ Immediate post-intervention } & \multicolumn{3}{|c|}{$\begin{array}{l}30 \text { days after the } \\
\text { intervention }\end{array}$} & \\
\hline & & Q1 & Median & Q3 & Q1 & Median & Q3 & Value $p$ \\
\hline & Pain (VAS) & 2.00 & 2.00 & 2.12 & 0.00 & 1.50 & 4.50 & 0.068 \\
\hline & Mouth Opening & 3.91 & 4.48 & 5.15 & 4.05 & 4.60 & 5.37 & 0.066 \\
\hline \multirow{8}{*}{ Ozone Therapy } & & \multicolumn{3}{|c|}{ Pre-intervention } & \multicolumn{3}{|c|}{$\begin{array}{c}30 \text { days after the } \\
\text { intervention }\end{array}$} & \\
\hline & & Q1 & Median & Q3 & Q1 & Median & Q3 & Value $p$ \\
\hline & Pain (VAS) & 2.75 & 3.75 & 5.62 & 0.00 & 0.50 & 5.50 & 0.141 \\
\hline & Mouth Opening & 3.69 & 3.91 & 4.50 & 4.25 & 5.00 & 5.07 & 0.144 \\
\hline & & \multicolumn{3}{|c|}{ Immediate post-intervention } & \multicolumn{3}{|c|}{$\begin{array}{l}30 \text { days after the } \\
\text { intervention }\end{array}$} & \\
\hline & & Q1 & Median & Q3 & Q1 & Median & Q3 & Value $p$ \\
\hline & Pain (VAS) & .50 & 1.16 & 1.33 & 0.00 & 0.50 & 5.50 & 1.000 \\
\hline & Mouth Opening & 4.25 & 4.43 & 4.82 & 4.25 & 5.00 & 5.07 & 0.273 \\
\hline \multirow{8}{*}{ Total } & & \multicolumn{3}{|c|}{ Pre-intervention } & \multicolumn{3}{|c|}{$\begin{array}{l}30 \text { days after the } \\
\text { intervention }\end{array}$} & \\
\hline & & Q1 & Median & Q3 & Q1 & Median & Q3 & Value $p$ \\
\hline & Pain (VAS) & 3.37 & 4.00 & 5.54 & 0.00 & 1.50 & 5.00 & 0.010 \\
\hline & Mouth Opening & 3.72 & 4.23 & 4.77 & 4.05 & 5.00 & 5.07 & 0.533 \\
\hline & & \multicolumn{3}{|c|}{ Immediate post-intervention } & \multicolumn{3}{|c|}{$\begin{array}{l}30 \text { days after the } \\
\text { intervention }\end{array}$} & \\
\hline & & Q1 & Median & Q3 & Q1 & Median & Q3 & Value $p$ \\
\hline & Pain (VAS) & 1.08 & 2.00 & 2.41 & 0.00 & 1.50 & 5.00 & 0.056 \\
\hline & Mouth Opening & 4.16 & 4.46 & 4.88 & 4.05 & 5.00 & 5.07 & 0.169 \\
\hline
\end{tabular}

Subtitle: Q1 (first quartile); Q3 (third quartile). (Wilcoxon test). In bold $(p<0.05)$.

\section{DISCUSSION}

In the present study, we chose to study TMD signs and symptoms in graduate students and undergraduate teachers. It can be stated that the hypothesis of the present study was proven. There was an improvement in quality of life and decreased pain perception in all groups receiving the treatments. According to literature, TMD has no defined etiology, and this disorder is a multifactorial condition and is directly related to several pathophysiological factors 2 .

According to Bove et al. ${ }^{4}$, the incidence of muscle TMD is between 15 and 30 years of age, and its prevalence, commonly, from four women to one $\operatorname{man}^{17}$, studies show that women of childbearing age are more vulnerable to the function of the female hormones ${ }^{18}$. 
Individuals with TMD may have discomfort, limited jaw movement, poor mouth opening, difficulty biting and cutting food, pain that radiates to various areas of the jaw, TMJ or head, and pain when chewing muscles or at ATM ${ }^{1}$. According to Caramêz et al. ${ }^{19}$, pain on palpation in these regions is directly linked to the presence of trigger points within the masticatory muscles. The following findings could be confirmed in our study, headaches, muscle aches, limitations in performing activities such as eating hard foods, TMJ crackles and painful trigger points were reported by most participants.

Studies claim that TMDs and headaches are directly related diseases, and their prevalence in the TMD population ranges from $48 \%$ to $77 \%$, while in the general population the prevalence is $45 \%{ }^{20}$. Other symptoms, such as joint noises, pain during mandibular movement, pain in the temporomandibular area, stress, depression, anxiety and poor sleep quality are symptoms that are linked to headaches ${ }^{20}$.

To investigate the signs and symptoms of individuals, as well as the diagnosis of muscle TMD, the study used the RDC/TMD12, corroborating similar studies found in the literature ${ }^{17}$. In addition, the present study found that all individuals had muscle pain and had masseter and temporal muscle pain, which is in line with studies found in the literature 21.

According to Okeson ${ }^{22}$, for the initial treatment of TMD, simple, reversible, minimally invasive and low-cost procedures should be chosen for patients.

In the study, the QoL related TMD was evaluated using the OHIP-14 instrument. These surveys of the OHIP-14 questionnaire try to relate the oral condition to each one's themes. It can be observed that there was no statistically significant difference in the comparison within each group when compared separately, either pre-intervention or post-intervention. But when all groups are compared with each other, there was a significant difference in pain-related QOL and physical inactivity-related QOL. These results are corroborated by more research found in the scientific literature ${ }^{23}$.

Individuals diagnosed with muscle TMD undergoing low-level laser therapy have been effective in treating pain and improving muscle function and quality of life, and it is estimated that its cumulative effect may be responsible for this improvement ${ }^{24}$. In addition, the results of the application of low-level laser therapy show that this therapy was effective in reducing pain during the observation period, but the study did not present statistically significant differences ${ }^{24}$. These results can be corroborated by the present study. The laser therapy group produced a very positive effect in terms of decrease and pain control in muscular TMD, showing increased maximum mouth opening and decreased pain, even without statistically significant difference.

In a randomized study, effects of trigger point acupuncture were compared with simulated acupuncture treatments on pain and oral function in TMD patients ${ }^{25}$. Pain intensity (visual analog scale) and oral function (maximum mouth opening) were analyzed. After treatment, pain intensity was lower in the trigger point acupuncture group, but oral function remained unchanged in both groups. The present study used assessment parameters similar to that study and found similar results, but there were no significant differences in pain improvement, not even in the maximum mouth opening in the analyzed periods.

There are few studies in the literature that use ozone to treat TMD ${ }^{8,9}$. González Rodríguez et al. ${ }^{26}$ used this alternative therapy for the treatment of TMD. These studies have shown that ozone therapy is a very effective treatment for relieving TMJ pain, when compared to pain medications ozone stands out. These results can be corroborated in the present study, the ozone therapy group showed a decrease in pain and improvement in maximal mouth opening, but without showing statistically higher differences from the laser therapy and ozone therapy groups.

It can be stated that the proposed therapies when analyzed in general were effective in reducing pain and improving maximum mouth opening. But when compared in isolation between them, neither group was more effective than the other. It is believed that there was no statistically significant difference in most of the analyzed variables, due to the size of the sample, which was a limiting factor of the study, as it was restricted due to the high rate of non-attendance by the individuals. Further studies in this area are needed to utilize these minimally invasive and cost-effective therapies for patients. 


\section{CONCLUSION}

Given the study, it can be considered that all treatments were able to decrease pain and improve maximal opening capacity related to muscle TMD. It can also be concluded that QoL related to TMD, in relation to the pain variable, was generally effective when compared before and after the interventions.

\section{ACKNOWLEDGEMENT}

Thanks to the Master's program in Human Aging at the University of Passo Fundo. This work was carried out with the support of the Higher Education Personnel Improvement Coordination (Capes) - Brazil, Financing Code 001.

\section{REFERENCES}

1. De Leeuw R. Dor orofacial: guia de avaliação, diagnóstico e tratamento 4. ed. São Paulo: Quintessence; 2010.

2. Barreto DC, Barbosa ART, Frizzo ACF. Relação entre disfunção temporomandibular e alterações auditivas. Rev CEFAC. 2010 Dez;12(6):1067-76. http://dx.doi.org/10.1590/S151618462010005000096.

3. Okeson JP. Orofacial pain. Guidelines for assessment, diagnosis and management. Chicago: Quintessence Publishing; 1996.

4. Bove SRK, Guimarães AS, Smith RL. Caracterização dos pacientes de um ambulatório de disfunção temporomandibular e dor orofacial. Rev Lat Am Enfermagem. 2005 Set-Out;13(5):686-91. http://dx.doi.org/10.1590/S0104-11692005000500012. PMid:16308625.

5. Furlan RMMM, Giovanardi RS, Britto ATBO, Brito DBO. 0 emprego do calor superficial para tratamento das disfunções temporomandibulares: uma revisão integrativa. CoDAS. 2015 Abr;27(2):207-12. http://dx.doi.org/10.1590/2317-1782/20152014148. PMid:26107088.

6. Rosted P. Practical recommendations for the use of acupuncture in the treatment of temporomandibular disorders based on the outcome of published controlled studies. Oral Dis. 2001 Mar;7(2):109-15. http://dx.doi.org/10.1034/j.1601-0825.2001.70208.x. PMid:11355435.

7. Mazzetto MO, Carrasco TG, Bidinelo EF, Andrade Pizzo RC, Mazzetto RG. Low intensity laser application in temporomandibular disorders: a phase I double-blind study. Cranio. 2007 Jul;25(3):18692. http://dx.doi.org/10.1179/crn.2007.029. PMid:17696035.

8. Daif ET. Role of intra-articular ozone gas injection in the management of internal derangement of the temporomandibular joint. Oral Surg Oral Med Oral Pathol Oral Radiol. 2012 Jun;113(6):e10-4. http://dx.doi.org/10.1016/j.tripleo.2011.08.006. PMid:22677023.

9. Doğan M, Ozdemir Doğan D, Düger C, Ozdemir Kol I, Akpinar A, Mutaf B, et al. Effects of high-frequency bio-oxidative ozone therapy in temporomandibular disorder-related pain. Med Princ Pract. 2014;23(6):507-10. http://dx.doi.org/10.1159/000365355. PMid:25196631.

10. Bocci V, Zanardi I, Travagli V. Ozone: A new therapeutic agent in vascular diseases. Am J Cardiovasc Drugs. 2011;11(2):73-82. http://dx.doi.org/10.2165/11539890-000000000-00000. PMid:21446774.

11. Rahimi-Movaghar V, Eslami V. The major efficient mechanisms of ozone therapy are obtained in intradiscal procedures. Pain Physician. 2012 Nov-Dec;15(6):E1007-8. PMid:23159972.

12. Dworkin SF, LeResche L. Research diagnostic criteria for temporomandibular disorders: review, criteria, examinations and specifications, critique. J Craniomandib Disord. 1992;6(4):301-55.

PMid:1298767. 
13. Soe KK, Gelbier S, Robinson PG. Reliability and validity of two oral health related quality of life measures in Myanmar adolescents. Community Dent Health. 2004 Dec;21(4):306-11. PMid:15617416.

14. Research Randomizer [Internet]. Randomizer; 2019 [cited 2019 Mar 25]. Available from: https://www.randomizer.org/

15. Brugnera JRA. Atlas de laserterapia aplicada à clínica odontológica. São Paulo: Santos; 2003.

16. Schwartz A, Sanchez GM, Sabah F. Declaración de Madrid sobre la ozonoterapia. 2. ed. Madrid: ISCO; 2015.

17. Branco RS, Branco CS, Tesch RS, Rapoport A. Frequência de relatos de parafunções nos sub-grupos diagnósticos de DTM de acordo com os critérios para pesquisa em disfunções temporomandibulares (RDC/TMD). Rev Dent Press Ortodon Ortop Facial. 2008 Abr;13(2):61-9. http://dx.doi.org/10.1590/S1415-54192008000200008.

18. Sartoretto SC, Bello YD, Bona AD, Azevedo MS. Evidências científicas para o diagnóstico e tratamento da DTM e a relação com a oclusão e a ortodontia. RF0. 2012 Set-Dez;17(3):352-9.

19. Caramês J, Carvalhão F, Real Dias MC. Dor miofascial por pontos gatilho, uma doença multidisciplinar. Acta Reumatol Port. 2009 Jan-Mar;34(1):38-43. PMid:19449474.

20. Di Paolo C, D’Urso A, Papi P, Di Sabato F, Rosella D, Pompa G, et al. Temporomandibular disorders and headache: a retrospective analysis of 1198 patients. Pain Res Manag. 2017;2017:1-8. http://dx.doi.org/10.1155/2017/3203027. PMid:28420942.

21. Fernández-Carnero J, La Touche R, Ortega-Santiago R, Galan-del-Rio F, Pesquera J, Ge HY, et al. shortterm effects of dry needling of active myofascial trigger points in the masseter muscle in patients with temporomandibular disorders. J Orofac Pain. 2010;24(1):106-12. PMid:20213036.

22. Okeson JP. Diagnóstico diferencial e considerações sobre o tratamento das desordens temporomandibulares. Chicago: Quintessence; 1998.

23. Rodrigues CA, Magri LV, Melchior MO, Mazzetto MO. Avaliação do impacto na qualidade de vida de pacientes com disfunção temporomandibular. Rev Dor. 2015 Jul-Set;16(3):181-5.

24. De Carli BM, Magro AK, Souza-Silva BN, Matos FS, De Carli JP, Paranhos LR, et al. The effect of laser and botulinum toxin in the treatment of myofascial pain and mouth opening: A randomized clinical trial. J Photochem Photobiol B. 2016 Jun;159:120-3. http://dx.doi.org/10.1016/j.jphotobiol.2016.03.038. PMid:27045280.

25. Itoh K, Asai S, Ohyabu H, Imai K, Kitakoji H. Effects of trigger point acupuncture treatment on temporomandibular disorders: a preliminary randomized clinical trial. J Acupunct Meridian Stud. 2012 Apr;5(2):57-62. http://dx.doi.org/10.1016/j.jams.2012.01.013. PMid:22483183.

26. González-Rodríguez CR, González SL, Carballido Perdomo DR, Fernández RB, Nieto Moreno R. Efectividad de la ozonoterapia para disminuir el dolor en los pacientes con trastornos temporomandibulares. Acta Médica del Centro. 2018;12(2):156-61.

\section{CONFLICTS OF INTERESTS}

The authors declare no conflicts of interest.

\section{*CORRESPONDING AUTHOR}

Leonardo Saraiva, Rua Capitão Eleutério, 151, AP 401, Centro, 99010-060 Passo Fundo - RS, Brasil, e-mail: leo77saraiva@hotmail.com

Received: December 3, 2019

Accepted: December 27, 2019 